\title{
PENGARUH UKURAN PARTIKEL DAN WAKTU PERENDAMAN AMPAS TEBU PADA PENINGKATAN KUALITAS MINYAK JELANTAH
}

\author{
Indah Nurdiani*, Suwardiyono, Laeli Kurniasari \\ Jurusan Teknik Kimia, Fakultas Teknik, Universitas Wahid Hasyim Semarang \\ J1. Menoreh Tengah X/22, Sampangan, Semarang 50236 \\ *Email : Indahdiani8@gmail.com
}

\begin{abstract}
Abstrak
Minyak jelantah adalah minyak goreng yang sudah digunakan beberapa kali pemakaian. Selain warnanya yang tidak menarik dan berbau tengik, minyak jelantah juga mempunyai potensi besar dalam membahayakan kesehatan tubuh. Minyak jelantah dapat dimanfaatkan kembali dengan cara mengadsorpsi kotoran-kotoran dan warna yang terdapat di dalam minyak jelantah dengan menggunakan adsorben. Penelitian ini bertujuan untuk memperbaiki kualitas minyak jelantah dilihat dari bilangan asam, bilangan penyabunan dan kadar air, beserta warna dari minyak jelantah dengan menggunakan adsorben ampas tebu dengan variasi ukuran 60 dan 80 mesh dengan waktu adsorpsi 1 hari, 2 hari dan 3 hari. Hasil penelitian terbaik untuk asam lemak bebas, bilangan penyabunan, dan massa jenis minyak berturut-turut adalah pada waktu 2 hari dengan ukuran ampas tebu $80 \mu \mathrm{m}$.
\end{abstract}

Kata kunci : Minyak jelantah, ampas tebu, adsorbsi

\section{PENDAHULUAN}

Salah satu dari sembilan bahan pokok yang dikonsumsi oleh seluruh lapisan masyarakat ialah minyak goreng. Minyak goreng adalah minyak yang berasal dari lemak tumbuhan atau hewan yang dimurnikan, berbentuk cair dalam suhu kamar dan biasanya digunakan untuk menggoreng makanan. Minyak goreng dari tumbuhan dihasilkan dari tanaman seperti kelapa, biji-bijian, kacang-kacangan, jagung dan kedelai (Kusumaningtyas, Ratna Dewi dkk. 2018).

Tanda rusaknya minyak goreng bisa dilihat dari sifat fisikokimianya. Kerusakan pada sifat fisikanya adalah warna pada minyak goreng yang mengalami perubahan, hal ini biasanya terjadi karena reaksi oksidasi dapat menyebabkan hilangnya warna karotenoid dalam makanan. Reaksi oksidasi karotenoid juga dipicu oleh suhu yang relatif tinggi. Karotenoid mengalami kerusakan oleh pemanasan pada suhu diatas $60^{\circ} \mathrm{C}$. Komponen utama yang menyebabkan warna pada minyak goreng adalah pigmen karoten sebagai penyumbang warna kuning, antosianin sebagai penyumbang warna merah dan klorofil sebagai penyumbang warna hijau (Aminullah dkk. 2018).

Minyak goreng dapat digunakan hingga 34 kali penggorengan. Akan tetapi, jika minyak goreng digunakan berulang kali, maka asam lemak yang terkandung akan semakin jenuh dan akan berubah warna. Minyak goreng bekas tersebut dikatakan telah rusak atau dapat disebut minyak jelantah dan kurang baik untuk dikonsumsi. Penggorengan makanan pada suhu tinggi, yang dilakukan dengan menggunakan minyak yang memiliki kadar asam lemak jenuh yang tinggi, mengakibatkan makanan menjadi berbahaya bagi kesehatan. Minyak goreng bekas yang terserap oleh makanan yang digoreng dan termakan oleh manusia akan masuk dan dicerna di dalam tubuh manusia.

Minyak goreng bekas yang masuk ke dalam tubuh manusia ini jika dibiarkan bertahun-tahun menumpuk di dalam tubuh akan menimbulkan penyakit bagi manusia, meskipun efeknya akan terlihat dalam jangka panjang. Beberapa potensi dampak buruk bagi kesehatan dapat terjadi akibat terlalu banyak mengkonsumsi minyak goreng bekas, misalnya adalah deposit lemak yang tidak normal, kanker, kontrol tak sempurna pada pusat syaraf (Ratna Dewi Kusumaningtyas dkk. 2018).

Pertumbuhan jumlah penduduk, serta perkembangan industri, restoran, dan usaha fastfood akan menyebabkan dihasilkannya minyak goreng bekas dalam jumlah yang cukup banyak. Namun apabila minyak goreng bekas tersebut dibuang sangatlah tidak efisien dan mencemari lingkungan. Karena itu minyak goreng bekas dapat dimanfaatkan kembali, salah satunya dengan menggunakan ampas tebu untuk meningkatkan kualitas minyak goreng bekas. 
Dewasa ini telah ditemukan suatu teknologi daur ulang mengolah minyak jelantah menjadi minyak layak pakai kembali dalam keadaan bersih tanpa kotoran, dengan menggunakan ampas tebu sebagai bahan penyerap. Bahan penyerap tebu yang sudah dijadikan partikel bisa langsung digunakan dengan mudah oleh ibu-ibu rumah tangga untuk memproses minyak jelantah menjadi minyak layak pakai. Penggunaan ampas tebu juga merupakan satu solusi mengurangi limbah padat perkotaan.

Ampas tebu adalah limbah dari hasil samping proses ekstraksi cairan tebu. Residu yang terkandung dalam ampas tebu berupa serat yang $50 \%$ seratnya diperlukan untuk bahan bakar boiler dan 50\% lagi sebagai limbah. Komposisi ampas tebu terdiri dari selulosa, hemiselulosa dan lignin. Ampas tebu mengandung selulosa yang di dalam struktur molekulnya mengandung gugus hidroksil atau gugus $\mathrm{OH}$. Minyak jelantah mengandung gugus-gugus yang dapat bereaksi dengan gugus $\mathrm{OH}$ dari selulosa sehingga zat warna tersebut dapat terikat pada ampas tebu. Zat warna reaktif dapat mewarnai serat selulosa dalam kondisi tertentu dan membentuk senyawa dengan ikatan kovalen atau ikatan hidrogen dengan selulosa (Farida Ali dkk. 2017).

Ramdja dkk. (2010), telah melakukan penelitian mengenai pemurnian minyak jelantah dengan proses adsorpsi menggunakan ampas tebu sebagai adsorben. Pemurnian ini dilakukan dengan menambahkan ampas tebu sebanyak 5$7 \%$ berat minyak ke dalam minyak jelantah dan direndam hingga $72 \mathrm{jam}$. Setelah dilakukan penyaringan didapatkan minyak dengan warna gelas yang telah berisi minyak, secara perlahan lebih jernih. Penelitian ini dilakukan menggunakan ukuran adsorben yang berbeda dengan penelitian sebelumnya. Selain itu penelitian ini dilakukan dengan membandingkan kadar analisis akhir setelah diproses menggunakan adsorben ampas tebu.

\section{Karakteristik Minyak}

Minyak merupakan salah satu kelompok yang termasuk kelompok lipida. Satu sifat yang khas dan mencirikan golongan lipida (termasuk minyak) adalah daya larutnya dalam pelarut organik (misalnya ether, benzene, khloroform) atau sebaliknya ketidak-larutannya dalam pelarut air.

Dalam teknologi makanan, minyak dan lemak memegang peranan penting. Karena minyak dan lemak memiliki titik didih yang tinggi (sekitar $200^{\circ} \mathrm{C}$ ) maka biasa dipergunakan untuk menggoreng makanan sehingga bahan yang digoreng akan kehilangan sebagian besar air yang dikandungnya dan menjadi kering. Minyak dan lemak juga memberikan rasa gurih spesifik minyak yang lain dari gurihnya protein.

Minyak kelapa adalah produk utama dari tanaman kelapa dan merupakan minyak nabati yang dipergunakan dalam pengolahan bahan pangan seperti dalam proses penggorengan. Selain itu, minyak kelapa memiliki berbagai kegunaan dalam bidang non pangan antara lain sebagai bahan dasar pembuatan sabun, margarin dan kosmetik. Minyak kelapa juga dapat digunakan secara tradisional seperti pada minyak lampu dan sebagai bahan bakar alternatif pengganti minyak solar dalam kendaraan bermesin diesel. Dalam teknologi pengolahan bahan pangan, minyak kelapa berperan penting untuk menggoreng makanan sehingga bahan pangan yang digoreng akan mengalami kehilangan banyak air dan menjadi kering.

\section{Minyak Jelantah}

Minyak yang telah dipakai menggoreng biasa disebut minyak jelantah. Kebanyakan minyak jelantah sebenarnya merupakan minyak yang telah rusak. Minyak yang tinggi kandungan LTJ (Lemak Tak Jenuh)-nya memiliki nilai tambah hanya pada gorengan pertama saja, sementara yang tinggi ALJ (Asam Lemak Jenuh)-nya bisa lebih lama lagi, meski pada akhirnya akan rusak juga.

Oleh proses penggorengan sebagian ikatan rangkap akan menjadi jenuh. Penggunaan yang lama dan berkali-kali dapat menyebabkan ikatan rangkap teroksidasi, membentuk gugus peroksida dan monomer siklik (Ramdja, dkk, 2010).

Secara umum, minyak goreng sangat rentan terhadap kerusakan oksidasi akibat proses penggorengan berulang yang digunakan di industri pangan. Reaksi ini akan mengakibatkan ketengikan dan membuat minyak goreng maupun produk gorengan mengalami penurunan mutu. Reaksi oksidasi pada minyak goreng dimulai dengan adanya pembentukan radikal-radikal bebas yang dipercepat oleh cahaya, panas, logam (besi dan tembaga), dan senyawa oksidator pada bahan pangan yang digoreng (seperti klorofil, hemoglobin, dan pewarna sintetik tertentu). Faktor lain yang mempengaruhi laju oksidasi 
adalah jumlah oksigen, derajat ketidakjenuhan asam lemak dalam minyak, dan adanya antioksidan.

Minyak kelapa yang digunakan untuk menggoreng dapat mengalami reaksi oksidasi yang disebabkan oleh suhu tinggi $\left( \pm 175-180^{\circ} \mathrm{C}\right)$ mengakibatkan kerusakan dengan menghasilkan bau dan cita rasa yang menyimpang dari aslinya. Reaksi oksidasi dapat menghasilkan produk bersifat toksik dan berdampak buruk bagi kesehatan. Selain itu hasil oksidasi minyak goreng sangat merusak sifat organoleptik sehingga minyak hampir tidak dapat digunakan lagi. Kerusakan minyak dan lemak ditandai dengan degradasi warna dan yang paling utama adalah terjadinya penyimpangan dalam bau dan rasa yang terjadi dalam proses ketengikan. Kemungkinan kerusakan atau ketengikan dalam lemak dapat disebabkan oleh 4 faktor yaitu : 1). Absorbsi bau oleh lemak. 2). Aksi oleh enzim dalam jaringan bahan yang mengandung lemak. 3). Aksi mikroba dan 4). Oksidasi oleh oksigen yang ada di udara atau kombinasi dari dua atau lebih dari penyebab kerusakan tersebut diatas.

Bentuk kerusakan pada minyak kelapa terutama ketengikan yang disebabkan oleh aksi oksigen yang ada di udara terhadap lemak. Dekomposisi lemak oleh mikroba hanya dapat terjadi jika terdapat air, senyawa nitrogen dan garam mineral. Sedangkan oksidasi oleh oksigen udara (autooksidasi) terjadi secara spontan jika bahan yang mengandung lemak dibiarkan kontak dengan udara sedangkan kecepatan proses oksidasinya tergantung dari tipe lemak itu sendiri. Kondisi penggorengan secara niaga sangat tidak menguntungkan, suhu yang terlalu tinggi selama minyak dipanaskan menyebabkan proses autooksidasi sangat dipercepat. Selain itu, beberapa perubahan lain dapat terjadi dalam minyak goreng, seperti asam lemak bebas dapat terbentuk dan warna dapat berubah menjadi gelap. Proses oksidasi diawali dengan pembentukan peroksida dan hidroperoksida. Tingkat selanjutnya adalah terurainya asam-asam lemak disertai dengan konversi hidroperoksida menjadi aldehid dan keton (Rorong, Johnly dkk, 2008).

\section{Proses Refinery Minyak Jelantah}

Pemucatan adalah suatu tahap proses pemurnian untuk menghilangkan zat-zat warna yang tidak disukai dalam minyak. Warna minyak mentah dapat berasal dari warna alamiah, yaitu warna yang dihasilkan oleh aktivitas biologis tanaman penghasil minyak, maupun warna yang didapat pada saat diproses untuk mendapatkan minyak dari bahan bakunya.

Selain dari proses pemucatan, minyak jelantah bisa dipakai kembali dalam keadaan bersih tanpa kotoran, dengan menggunakan ampas tebu sebagai bahan penyerap. Bahan penyerap tebu yang sudah dijadikan partikel bisa langsung digunakan dengan mudah oleh ibu-ibu rumah tangga untuk memproses minyak jelantah menjadi minyak layak pakai. Ampas tebu dalam analisa itu berfungsi sebagai bahan penyerap yang bagus, selain itu penggunaan ampas tebu merupakan satu solusi mengurangi limbah padat perkotaan.

\section{Analisa Minyak}

Analisa lemak dan minyak yang umum dilakukan pada bahan makanan dapat digolongkan dalam tiga kelompok :

1. Penentuan kuantitatif atau penentuan kadar lemak atau minyak yang terdapat dalam bahan makanan.

2. Penentuan kualitas minyak (murni) sebagai bahan makanan yang berkaitan dengan proses ekstraksinya, atau ada tidaknya perlakuan pemurnian lanjutan misalnya penjernihan (refining), penghilangan bau (deodorizing), penghilangan warna (bleaching), dan sebagainya. Penentuan tingkat kemurnian minyak ini sangat berhubungan erat dengan kekuatan daya simpannya, sifat gorengnya, baunya maupun rasanya. Tolok ukur kualitas ini termasuk angka asam lemak bebas (Free Fatty Acid atau FFA), bilangan peroksida, tingkat ketengikan, bilangan penyabunan dan kadar air.

3. Penentuan sifat fisis maupun kimiawi yang khas atau mencirikan sifat minyak tertentu.

\section{Penentuan Kualitas Minyak}

\section{Kadar Air}

Air bila terdapat dalam minyak dapat mempercepat terjadinya hidrolisa minyak menjadi gliserol atau asam lemak (FFA). Bila minyak terhidrolisa, maka minyak akan menjadi tengik sehingga dapat menurunkan kualitas minyak. Reaksi hidrolisa minyak dapat terjadi selama penyimpanan. Kadar Asam Lemak Bebas (Free Fatty Acid / FFA)

Asam lemak bebas ditentukan sebagai kandungan asam lemak yang terdapat paling banyak dalam minyak tertentu. Demikian asam 
lemak bebas berikut ini dipakai sebagai tolok ukur jenis minyak tertentu, berdasarkan jenisjenis asam lemak bebasnya.

Hubungan kadar asam lemak (\%FFA) dengan angka asam dapat dituliskan sebagai berikut:

Angka Asam $=\frac{B M K O H}{(B M F F A / 10)} \times \%$ FFA

Angka asam $=$ Faktor konversi $\mathrm{x} \%$ FFA

Faktor konversi untuk Oleat $=1,99$

Faktor konversi untuk Palmitat $=2,19$

Faktor konversi untuk Laurat $=2,80$

Faktor konversi untuk Linoleat $=2,01$

Penentuan Angka Penyabunan

Angka penyabunan (Saponification Value) menunjukkan secara relatif besar kecilnya molekul asam-asam lemak yang terkandung dalam gliserida. Angka penyabunan dinyatakan sebagai banyaknya mg KOH yang dibutuhkan untuk menyabunkan minyak secara sempurna dari 1 gram minyak tersebut.

Alkohol yang ada dalam $\mathrm{KOH}$ berfungsi untuk melarutkan asam lemak hasil hidrolisa dan mempermudah reaksi dengan basa sehingga terbentuk sabun. Sehingga semakin besar angka penyabunan maka asam lemak akan semakin kecil dan kualitas minyak akan semakin bagus, sebaliknya jika angka penyabunan kecil maka asam lemak besar dan kualitas menurun. Besarnya angka penyabunan tergantung dari massa molekul minyak, semakin besar massa molekul semakin rendah angka penyabunannya (Ramdja dkk, 2010).

Kerusakan minyak akibat pemanasan dapat diamati dari perubahan warna, kenaikan kekentalan, peningkatan bilangan peroksida. Selain itu dapat juga dilihat dari penurunan bilangan iod dan penurunan asam lemak tak jenuh. Berikut ini pada Tabel 1 dapat dilihat standart persyaratan minyak goreng yang layak dikonsumsi.

Tabel 1. Standart Mutu Minyak Goreng

\begin{tabular}{|c|c|c|}
\hline $\mathrm{NO}$ & Kriteria & Pesyaratan \\
\hline 1. & Bau dan Rasa & Normal \\
\hline 2. & Warna & $\begin{array}{l}\text { Putih, kuning pucat } \\
\text { sampai kuning }\end{array}$ \\
\hline 3. & Kadar Air & Max $0.3 \%$ b/b \\
\hline 4. & Asam Lemak bebas & \\
\hline & Asam Laurat & Maks $0,3 \% \mathrm{~b} / \mathrm{b}$ \\
\hline & Asam linoleat & Maks $2,00 \% \mathrm{~b} / \mathrm{b}$ \\
\hline & Asam palmitat & Maks $0,30 \% \mathrm{~b} / \mathrm{b}$ \\
\hline & Asam oleat & Maks $0,30 \% \mathrm{~b} / \mathrm{b}$ \\
\hline 5. & Bilangan Asam & Maks. 0,6 mg \\
\hline
\end{tabular}

\begin{tabular}{|c|c|c|}
5. & Berat Jenis & KOH/g \\
6. & Bilangan Peroksida & Max 2 Meq//iter \\
7. & Bilangan & $196-206$ \\
& Penyabunan & \\
8. & Indeks Bias & $1,448-1,450$ \\
9. & Cemaran logam & $\begin{array}{c}\text { Max } 0,1 \mathrm{mg} / \mathrm{kg} \\
\text { (Kecuali seng) }\end{array}$ \\
\hline
\end{tabular}

(Sumber : SNI 01-3741-2002 Standar Mutu Minyak Goreng)

\section{Tebu (Sugar Cane)}

Tebu (Sacharum officinarum, Linn.) merupakan tanaman bahan baku pembuatan gula yang hanya dapat ditanam di daerah beriklim tropis. Umur tanaman sejak ditanam sampai bisa dipanen mencapai kurang lebih satu tahun. Tebu termasuk keluarga Graminae atau rumput-rumputan dan cocok ditanam pada daerah dengan ketinggian 1 sampai 1300 meter di atas permukaan air laut. Tebu dari perkebunan diolah menjadi gula di pabrik gula. Dalam proses produksi gula, dari setiap tebu yang diproses dihasilkan ampas tebu sebesar $90 \%$, gula yang dimanfaatkan hanya $5 \%$ dan sisanya berupa tetes tebu (molase) dan air. Ampas tebu merupakan limbah pabrik gula yang sangat mengganggu apabila tidak dimanfaatkan. Ampas tebu mengandung serat (selulosa, pentosan, dan lignin), abu, dan air (Farida Ali dkk. 2017).

Ampas tebu umumnya digunakan sebagai bahan bakar untuk menghasilkan energi yang diperlukan pada pembuatan gula. Selain itu, ampas tebu dapat juga digunakan sebagai pakan ternak, bahan baku serat, papan, plastik, dan kertas. Ampas tebu juga dapat dimanfaatkan sebagai adsorben logam berat seperti seng, kadmium, tembaga, dan timbal (Farida Ali dkk. 2017).

Ampas tebu ini dapat pula dijadikan arang aktif sebagai adsorben. Hal ini dikarenakan ampas tebu memiliki kandungan selulosa dan pori-pori yang baik yang dapat mengikat partikel setelah di aktivasi. Dengan pemanfaatan ampas tebu sebagai adsorben dan arang aktif ini dapat mengurangi limbah ampas tebu di sekitar pabrik pembuatan gula yang dapat menyebabkan pencemaran lingkungan (Farida Ali dkk. 2017).

Hasil analisis serat bagas tercantum dalam Tabel 2 (Ramdja dkk 2010) 
Tabel 2. Komposisi Kimia Ampas Tebu

\begin{tabular}{cc}
\hline Kandungan & Kadar $(\%)$ \\
\hline Abu & 0,79 \\
Lignin & 12,7 \\
Selulosa & 44,7 \\
Sari & 2 \\
Pentosa & 27,9 \\
\hline
\end{tabular}

\section{Rancangan Penelitian}

Variabel yang digunakan dalam penelitian ini adalah sebagai berikut :

- Lama perendaman :

1 hari, 2 hari, 3 hari

- Ukuran partikel ampas tebu :

$60 \mu \mathrm{m}$ dan $80 \mu \mathrm{m}$.

\section{Alat dan bahan yang digunakan :}

Alat yang digunakan yaitu erlenmeyer, alat titrasi, beaker gelas, hot plate, pipet tetes, termometer, pengaduk, ayakan, kertas saring, neraca analitis, blender. Adapun bahan yang digunakan adalah minyak jelantah, minyak goreng baru, $\mathrm{KOH}$, Indikator PP, ampas tebu, aquadest, alkohol

\section{Prosedur Penelitian :}

1. Siapkan ampas tebu yang diperoleh dari sisa-sisa penggilingan sari tebu.

2. Kemudian cuci bersih ampas tebu tersebut dari kotoran-kotoran yang melekat.

3. Keringkan ampas tebu tersebut di bawah terik matahari. Selanjutnya giling ampas tebu yang telah kering hingga menjadi bubuk tebu.

4. Bubuk tebu tersebut di ayak dengan berbagai variasi ukuran diameter partikel.

5. Siapkan minyak goreng yang telah dipakai beberapa kali (jelantah) dan juga minyak goreng yang bagus (baru).

6. Analisis terlebih dahulu kandungan pada minyak jelantah dan minyak yang baru.

7. Siapkan minyak goreng yang telah dipakai beberapa kali (jelantah) dan juga minyak goreng yang bagus(baru).

8. Masukan bubuk ampas tebu kedalam masing masing minyak tersebut.

9. Rendam ampas tebu kedalam minyak, lalu disaring sesuai dengan variabel waktu.

10. Analisa minyak yang sebelumnya telah direndam dengan ampas tebu dan telah disaring.

\section{Penentuan Kadar Air}

Penentuan kadar air minyak dengan cara Thermogravimetri sebagai berikut :
1. Timbang \pm 10 gram minyak(A) dalam cawan porselin.

2. Oven pada suhu $105^{\circ} \mathrm{C}$ sampai berat konstan, lalu timbang berat konstan(B).

Kadar Air $=\left(\frac{A-B}{A}\right) \times 100$

\section{Penentuan Asam Lemak Bebas (FFA)}

1. Bahan harus diaduk merata dan berada dalam keadaan cair pada waktu diambil contohnya. Timbang sebanyak $28,2 \pm 0,2 \mathrm{~g}$ contoh dalam Erlenmeyer. Tambahkan 50 $\mathrm{ml}$ alkohol netral yang panas dan $2 \mathrm{ml}$ indikator phenolphthalein (PP).

2. Titrasilah dengan larutan $0,1 \mathrm{~N} \mathrm{NaOH}$ yang telah di standarisasi sampai warna merah jambu tercapai dan tidak hilang selama 30 detik.

3. Persen asam lemak bebas dinyatakan sebagai oleat pada kebanyakan minyak dan lemak. Untuk minyak kelapa dan minyak inti kelapa sawit dinyatakan sebagai laurat, sedang pada minyak kelapa sawit dinyatakan sebagai palmitat.

Asam lemak bebas dinyatakan sebagai \% FFA. Penentuan kadar asam lemak bebas (Free Fatty Acid) pada minyak :

96 FFA $=\left(\frac{(m L N a O H \times N \text { NaOH } \times \text { BM Asam Lemak })}{(\text { Berat sampel } \times 1000)}\right) \times 100$

\section{Penentuan Angka Penyabunan}

1. Timbang minyak dengan teliti antara 1,5 - 5,0 gram dalam Erlenmeyer $200 \mathrm{ml}$. Tambah $50 \mathrm{ml}$ larutan $\mathrm{KOH}$ yang dibuat dari 40 gram KOH dalam 1 liter alkohol.

2. Tutup dengan pendingin balik, didihkan dengan hati-hati selama 30 menit.

3. Dinginkan dan tambahkan beberapa tetes indikator phenolphthalein (PP) dan titrasilah kelebihan larutan $\mathrm{KOH}$ dengan standar 0,5 N HCL. Untuk mengetahui kelebihan larutan $\mathrm{KOH}$ ini perlu dibuat titrasi blanko, yaitu dengan prosedur yang sama kecuali tanpa bahan minyak.

4. Angka penyabunan dinyatakan sebagai banyaknya $\mathrm{mg} \mathrm{KOH}$ yang dibutuhkan untuk menyabunkan minyak secara sempurna dari 1 gram minyak tersebut.

Bilangan Penyabunan $=\frac{(28,05 \times(m L \text { Blangko }-m L \text { Sampel }))}{\text { Gram Sampel }}$ 


\section{HASIL DAN PEMBAHASAN}

Pada penelitian ini pengujian yang dilakukan meliputi penentuan angka asam dengan menentukan kadar asam lemak bebas dan penentuan bilangan penyabunan. Beberapa studi menyebutkan uji di atas sudah cukup dapat menggambarkan kualitas minyak. Walaupun begitu, akan lebih baik lagi jika dilakukan pemeriksaan secara fisika, yakni dengan penetapan kadar air. Sebelumnya dilakukan pengujian pada minyak goreng bekas tanpa variasi suhu dan penambahan ampas tebu dengan variasi waktu perendaman( 24 jam, 48 jam dan 72 jam) serta variasi ukuran ampas tebu $(60 \mu \mathrm{m}$ dan $80 \mu \mathrm{m})$.

Sebelumnya dilakukan perbandingan secara visual antara minyak goreng baru, minyak jelantah, kemudian berturut-turut minyak jelantah yang telah diadsorb selama 1 hari, 2 hari, dan 3 hari.

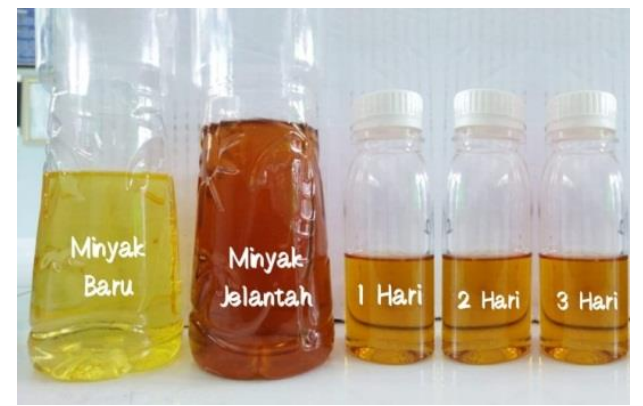

Gambar 1. Perbandingan warna minyak jelantah dengan ampas tebu berukuran $60 \mu \mathrm{m}$

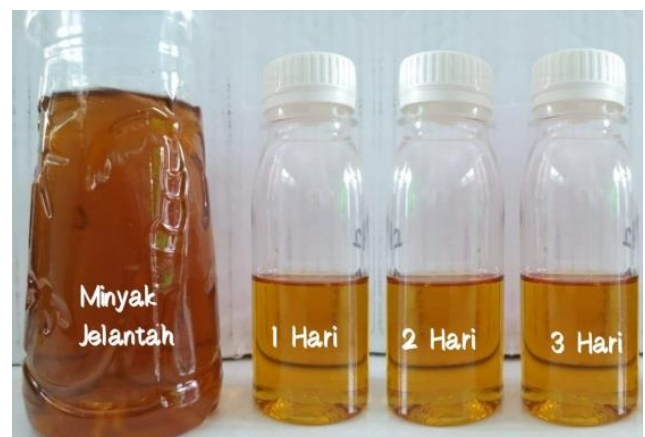

Gambar 2.Perbandingan warna minyak jelantah dengan ampas tebu berukuran $80 \mu \mathrm{m}$.

Jika dilihat dari hasil percobaan diatas, secara visual minyak jelantah mengalami perubahan warna menjadi lebih cerah jika dibandingkan minyak jelantah yang tidak direndam menggunakan ampas tebu. Namun dari ketiga minyak hasil perendaman dengan ampas tebu menghasilkan warna yang relatif sama, baik menggunakan ampas tebu dengan ukuran $60 \mu \mathrm{m}$ maupun $80 \mu \mathrm{m}$.

\section{ANALISA KADAR AIR}

Penentu tingkat kerusakan minyak dapat dilihat dengan adanya air dalam minyak. Minyak akan lebih mudah mengalami proses hidrolisis bila sudah tercampur dengan air, yang merupakan awal dari proses peruraian minyak selanjutnya.

Minyak yang mengandung makin banyak air, semakin meningkat hidrolisisnya. Air yang ditetapkan ini adalah air yang terikat secara fisik dengan minyak. Prinsip penetapan kadar air dengan metode oven adalah menguapkan air yang terkandung dalam minyak dengan cara dikeringkan dalam oven selama kurang lebih 4 jam pada suhu $100-105^{\circ} \mathrm{C}$ untuk mendapatkan berat yang konstan. Berat konstan menunjukkan bahwa kandungan air pada minyak telah menguap seluruhnya, dan hanya tersisa berat kering minyak itu sendiri. Air adalah konstituen yang keberadaannya dalam minyak sangat tidak diinginkan karena akan menghidrolisis minyak menghasilkan asam - asam lemak bebas yang menyebabkan bau tengik pada minyak. Hasil analisis kadar air minyak goreng dapat dilihat pada Tabel 3.

Kadar air sangat penting dalam menentukan daya awet dari bahan makanan karena mempengaruhi sifat fisik, kimia, perubahan mikrobiologi, dan perubahan enzimatis. Kandungan air dalam bahan makanan ikut menentukan penerimaan konsumen, kesegaran, dan daya tahan bahan. Kandungan air yang tinggi pada bahan menyebabkan daya tahan bahan rendah. Untuk memperpanjang daya tahan suatu bahan, sebagian air dalam bahan harus dihilangkan dengan berbagai cara tergantung jenis bahan. Minyak goreng juga mudah terkontaminasi oleh udara dan air (teroksidasi) yang dapat menimbulkan ketengikan sehingga mempengaruhi cita rasa, daya simpan minyak goreng tersebut menjadi lebih singkat.

Dari tabel diatas dapat disimpulkan bahwa lama perendaman dan ukuran partikel ampas tebu mempengarui hasil kadar air minyak goreng bekas. Bila dibandingkan dengan syarat SNI 01-3741-2002 yaitu maksimal $0,3 \%$ b/b, minyak goreng yang direndam selama 1 hari dengan ukuran partikel $60 \mu \mathrm{m}$ memiliki kadar air lebih dari $0,3 \%$ yaitu 0,4940. Bila dibandingkan dengan minyak jelantah yang belum direndam yaitu $0,5294 \%$ maka sudah 
mengalami penurunan. Hasil kadar air minyak pada perendaman selama satu hari dengan ukuran partikel $80 \mu \mathrm{m}$ mengalami penurunan kadar air yang signifikan yaitu $0,2381 \%$, kemudian dilanjutkan perendaman selama 2 hari dengan ukuran partikel $60 \mu \mathrm{m}$ dan $80 \mu \mathrm{m}$, didapat hasil berturut-turut $0,2364 \%$ dan $0,1987 \%$.

Hasil kadar air yang diperoleh tidak mengalami penurunan yang tajam dari hari kedua ke hari ketiga dan cenderung sama. Hal ini menunjukan jika dalam waktu 2 hari ampas tebu dapat menyerap air yang terkandung pada ampas tebu secara optimal baik menggunakan ukuran partikel $60 \mu \mathrm{m}$ maupun $80 \mu \mathrm{m}$. Namun bila dibandingkan ukuran partikel $80 \mu \mathrm{m}$ lebih menyerap kadar air secara optimal, hal ini dikarenakan semakin kecil ukuran partikel maka semakin luas pula daya sentuh adsorben terhadap bahan yang akan di adsorb.

\section{ANALISA ASAM LEMAK BEBAS dan BILANGAN ASAM}

Pada penelitian ini metode yang digunakan adalah metode titrasi dengan larutan standart $\mathrm{NaOH} 0.1 \mathrm{~N}$. Minyak ditambah alkohol, tujuan penambahan alkohol agar minyak dapat larut dan dapat bereaksi dengan basa alkali sehingga mudah untuk dititrasi. Kenaikan bilangan asam lemak bebas juga dapat disebabkan karena kadar air yang tinggi sehingga mempercepat hidrolisis dari minyak goreng. Keberadaan air pada minyak akan mempercepat proses hidrolisis dari minyak goreng. Asam lemak bebas merupakan asam yang dihasilkan pada saat hidrolisa lemak. Asam lemak bebas yang terdapat di dalam minyak kelapa sawit normalnya $<1 \%$, nilai asam lemak bebas $>1 \%$ menyebabkan minyak berbau tengik. Dengan demikian, semakin tinggi kadar asam lemak bebas maka dapat menurunkan kualitas minyak dan minyak dapat berubah menjadi tengik. Hasil analisa nilai asam lemak bebas dan bilangan asam dapat dijelaskan pada Tabel 4 dan Tabel 5.

Tabel 4. Analisa kadar asam lemak bebas minyak goreng

\begin{tabular}{|c|c|c|}
\hline \multicolumn{2}{|r|}{ Variabel } & \multirow{2}{*}{$\begin{array}{l}\text { Kadar Asam } \\
\text { Lemak Bebas } \\
(\% \text { b/b) }\end{array}$} \\
\hline Hari ke- & Ukuran Partikel & \\
\hline 1 & $60 \mu \mathrm{m}$ & 0,4193 \\
\hline 1 & $80 \mu \mathrm{m}$ & 0,3340 \\
\hline 2 & $60 \mu \mathrm{m}$ & 0,3647 \\
\hline
\end{tabular}

\begin{tabular}{|c|c|c|}
\hline 2 & $80 \mu \mathrm{m}$ & 0,3089 \\
\hline 3 & $60 \mu \mathrm{m}$ & 0,3642 \\
\hline 3 & $80 \mu \mathrm{m}$ & 0,3371 \\
\hline Minyak Baru & 0,2248 \\
\hline Minyak Jelantah & 0,4755 \\
\hline \multicolumn{2}{|c|}{$\begin{array}{l}\text { Syarat SNI SNI 01-3741- } \\
\text { 2002 }\end{array}$} & Maks 0,3 \\
\hline
\end{tabular}

Tabel 5. Hasil bilangan Asam minyak goreng

\begin{tabular}{|c|c|c|}
\hline \multicolumn{2}{|c|}{ Variabel } & Bilangan \\
\hline Hari ke- & $\begin{array}{l}\text { Ukuran } \\
\text { Partikel }\end{array}$ & $\begin{array}{l}\text { Asam (mg } \\
\mathrm{KOH} / \mathrm{g})\end{array}$ \\
\hline 1 & $60 \mu \mathrm{m}$ & 0,8326 \\
\hline 1 & $80 \mu \mathrm{m}$ & 0,6633 \\
\hline 2 & $60 \mu \mathrm{m}$ & 0,7243 \\
\hline 2 & $80 \mu \mathrm{m}$ & 0,6135 \\
\hline 3 & $60 \mu \mathrm{m}$ & 0,7232 \\
\hline 3 & $80 \mu \mathrm{m}$ & 0,6695 \\
\hline \multicolumn{2}{|c|}{ Minyak Baru } & 0,4463 \\
\hline \multicolumn{2}{|c|}{ Minyak Jelantah } & 0,9443 \\
\hline \multicolumn{2}{|c|}{$\begin{array}{c}\text { Syarat SNI SNI 01-3741- } \\
2002\end{array}$} & Maks. 0,6 \\
\hline
\end{tabular}

Berdasarkan kedua tabel menunjukkan bahwa sampel minyak goreng bekas pakai tidak memenuhi syarat kelayakan untuk pemakaian atau dikonsumsi karena nilai persen asam lemak bebas dan bilangan asamnya tidak memenuhi standar mutu minyak goreng.

Minyak baru memiliki asam lemak bebas rendah atau bilangan asam rendah. Trigliserida, karena adanya air, terhidrolisis menjadi gliserol dan asam lemak bebas. Tingginya bilangan asam ini artinya setara dengan tinggi pula kadar asam lemak bebasnya. Trigliserida yang terkandung di dalam sudah banyak yang terurai menjadi asam lemak bebasnya akibat reaksi hidrolisa. Hal ini bisa terjadi pada proses pemanasan minyak pada suhu tinggi dan berulang-ulang.

Berdasarkan Tabel 4 dan 5, dapat dilihat pengaruh waktu adsorpsi dan ukuran adsorben terhadap kadar asam lemak bebas. Semakin kecil ukuran ampas tebu dan waktu adsorpsi yang semakin lama, maka nilai asam lemak bebas cenderung menurun. Hal ini dikarenakan waktu adsorpsi yang lama menyebabkan semakin kecil dan semakin lama terjadinya kontak antara permukaan adsorben dan minyak jelantah. Semakin kecil ukuran adsorben maka semakin baik proses adsorpsi yang berlangsung karena semakin luas permukaan tempat terjadinya proses adsorpsi dan waktu kontak yang semakin lama menyebabkan semakin 
banyak jumlah asam lemak bebas yang diikat oleh permukaan adsorben.

Ukuran partikel adsorben sangat berpengaruh terhadap kapasitas adsorben dalam proses adsorbsi. Dapat dilihat dari hasil analisa asam lemak pada Tabel 4, bahwa terdapat selisih yang signifikan antara minyak yang menggunakan adsorben ukuran $60 \mu \mathrm{m}$ dan 80 $\mu \mathrm{m}$. Sesuai dengan teori ukuran adsorben diatas. Namun hasil yang didapat pada hari ketiga tidak beda jauh dengan hari kedua.

Dapat disimpulkan bahwa adsorben telah melewati waktu optimum adsorben. Hal ini terjadi karena adsorben telah jenuh oleh adsorbat, sehingga bila dilanjutkan kemungkinan akan terjadi proses pelepasan kembali adsorben oleh adorben. Pada hasil kadar asam lemak bebas mesh $80 \mu \mathrm{m}$ dengan waktu rendam 3 hari mengalami kenaikan kadar asam lemak bebas bahkan melebihi hasil pada hari pertama. Dugaan sementara karena terjadinya kesalahan saat proses penyaringan, yaitu terjadi penekanan pada ampas tebu di kertas saring yang menyebabkan minyak yang telah terserap oleh ampas tebu terlepas kembali. Sedangkan bilangan asam didapat dengan mengalikan kadar asam lemak bebas dengan faktor konversi, yaitu bobot molekul (BM) $\mathrm{KOH}(56,1 \mathrm{~g} / \mathrm{mol})$ dibagi persepuluh $\mathrm{BM}$ asam lemak.

Nilai bilangan asam minyak jelantah tergolong tinggi yaitu $0,9443 \mathrm{mg} \mathrm{KOH} / \mathrm{g}$. Untuk menetralkan asam lemak-asam lemak dalam minyak jelantah hitam tersebut sampai diperlukan $\mathrm{KOH}$ lebih dari 1 miligram setiap 100 gram minyak. Tingginya bilangan asam ini artinya setara dengan tinggi pula kadar asam lemak bebasnya. Trigliserida yang terkandung di dalam sudah banyak yang terurai menjadi asam lemak bebasnya akibat reaksi hidrolisa. Hal ini bisa terjadi pada proses pemanasan minyak pada suhu tinggi dan berulang-ulang.

Setelah melihat seluruh hasil analisa asam lemak bebas terhadap sampel minyak jelantah hasil purifikasi, dapat dilihat jika dibandingkan dengan syarat SNI 01-3741-2002 masih belum memenuhi syarat.

\section{ANALISA BILANGAN PENYABUNAN}

Penentu tingkat kerusakan minyak selanjutnya adalah bilangan penyabunan, dengan menunjukkan secara relatif besar kecilnya molekul asam-asam lemak yang terkandung dalam gliserida. Bilangan penyabunan dinyatakan sebagai banyaknya (mg) $\mathrm{KOH}$ yang dibutuhkan untuk menyabunkan satu gram minyak atau lemak, alkohol yang ada dalam $\mathrm{KOH}$ berfungsi untuk melarutkan asam lemak hasil hidrolisa dan mempermudah reaksi dengan basa sehingga terbentuk sabun. Sehingga semakin besar angka penyabunan maka asam lemak akan semakin kecil dan kualitas minyak akan semakin bagus, sebaliknya jika angka penyabunan kecil maka asam lemak besar dan kualitas menurun.

Angka penyabunan adalah angka yang menunjukkan jumlah miligram $\mathrm{KOH}$ yang dibutuhkan untuk menyabunkan 1 gram minyak. Besarnya angka penyabunan tergantung dari massa molekul minyak, semakin besar massa molekul semakin rendah angka penyabunannya.

Hasil pemeriksaan bilangan penyabunan yang dilakukan dapat dilihat pada Tabel 6 dibawah ini.

Tabel 6. Analisa Bilangan Penyabunan Minyak Goreng

\begin{tabular}{|c|c|c|}
\hline \multicolumn{2}{|r|}{ Variabel } & \multirow{2}{*}{$\begin{array}{l}\text { Bilangan } \\
\text { Penyabunan }\end{array}$} \\
\hline Hari ke- & Ukuran Partikel & \\
\hline 1 & $60 \mu \mathrm{m}$ & 193,9929 \\
\hline 1 & $80 \mu \mathrm{m}$ & 197,9670 \\
\hline 2 & $60 \mu \mathrm{m}$ & 196,9570 \\
\hline 2 & $80 \mu \mathrm{m}$ & 198,6330 \\
\hline 3 & $60 \mu \mathrm{m}$ & 196,3030 \\
\hline 3 & $80 \mu \mathrm{m}$ & 197,9780 \\
\hline \multicolumn{2}{|c|}{ Minyak Baru } & 199,7630 \\
\hline \multirow{2}{*}{\multicolumn{2}{|c|}{ Minyak Jelantah }} & 189,1640 \\
\hline & & $196-206$ \\
\hline
\end{tabular}

Sama halnya dengan Tabel 4 dan 5, tabel di atas juga memperlihatkan angka penyabunan yang semakin lama perendaman semakin kecil pula angka penyabunan. Namun sama pula seperti tabel sebelumnya, bahwa penelitian menunjukkan kenaikan angka penyabunan setelah minyak tersebut diolah.

Untuk laju penurunan angka penyabunan pada grafik ini, perubahan tidak terjadi secara drastis. Pada waktu perendaman selama 1 hari dan 2 hari, terjadi perubahan yang begitu kecil. Perubahan yang tidak begitu besar ini disebabkan karena daya adsorpsi dalam rentang waktu perendaman ampas tebu tidak begitu jauh berbeda.

Ukuran partikel ampas tebu yang semakin kecil juga sangat mempengaruhi kemampuan ampas tebu dalam mengadsorpsi. Semakin kecil 
ukuran partikel ampas tebu, maka proses adsorpsi akan berjalan semakin baik.

Dalam analisa Tabel 6 ini ditemukan kondisi optimum, dimana nilai angka penyabunan yang paling mendekati minyak baru pada perendaman selama 2 hari dengan ukuran partikel $80 \mu \mathrm{m}$. Hasil ini sama hal nya dengan hasil kadar asam lemak bebas yang didapat.

Minyak yang disusun oleh asam lemak berantai $\mathrm{C}$ pendek berarti mempunyai berat molekul relatif kecil akan mempunyai bilangan penyabunan yang besar dan jumlah $\mathrm{KOH}$ yang dibutuhkan untuk menyabunkan 1 gram lemak atau minyak juga semakin banyak. Begitu pula sebaliknya. Secara teori bilangan penyabunan dapat dipergunakan untuk menentukan berat molekul minyak dan lemak secara kasar. Peningkatan bilangan penyabunan dipengaruhi oleh berat ampas tebu, karena penambahan ampas tebu dapat memecah ikatan rantai $\mathrm{C}$ pada minyak goreng bekas. Selain itu, semakin lama waktu pengadukan maka molekul-molekul asam lemak yang terdapat dalam minyak akan semakin pecah, berat molekul minyak goreng bekas akan menjadi semakin kecil sehingga bilangan penyabunan yang diperoleh semakin besar (Hesti Wijayanti dkk,2016).

\section{KESIMPULAN}

Dari hasil penelitian yang telah dilakukan, dapat disimpulkan beberapa hal, antara lain :

Ampas tebu merupakan serat yang dapat digunakan sebagai adsorben untuk mengikat pengotor pada minyak.

1. Kadar air dalam minyak dapat diturunkan hingga $0,331 \%$, kadar FFA minyak bekas pakai dapat diturunkan hingga $0,169 \%$, dan angka penyabunan dapat mencapai angka 198,633 .

2. Lama perendaman mempengaruhi hasil penjernihan minyak yang diharapkan. Dari hasil penelitian membuktikan bahwa waktu yang optimal adalah 2 hari.

3. Semakin kecil diameter partikel adsorben (ampas tebu), pada penelitian ini maka penyerapan zat pengotor berlangsung semakin optimal.

\section{DAFTAR PUSTAKA}

Aminullah, D Kuswandi, dan SI Rahmawati, 2018, Perubahan Sifat Fisikokimia Minyak Sawit Bekas Pakai(Jelantah) Pada Penggorengan Daging Ayam, Program Study Teknologi Pangan dan
Gizi, Fakultas Pangan Ilmu Halal, Universitas Djuanda Bogor.

Badan Standardisasi Nasional, Standar Minyak Goreng: SNI 01-3741-2002, Jakarta, 2002.

Farida Ali, Annisa Rahmathul Fithri, dan Rifky Harisya Adhitya, 2017, Pemanfaatan Limbah Karet Alam Dan Ampas Tebu Sebagai Adsorben Crude Oil Spills, Jurnal Teknik Kimia, Universitas Sriwijaya.

Hesti Wijayanti, Harmin Nora, Rajihah Amelia, 2012, Pemanfaatan Arang Aktif Dari Serbuk Gergaji Kayu Ulin Untuk Meningkatkan Kualitas Minyak Goreng Bekas, Program Study Teknik Kimia, Fakultas Teknik, Universitas Lambung Mangkurat.

Ramdja, A. Fuadi, Lisa Febriana, dan Daniel Krisdianto, 2010, Pemurnian Minyak Jelantah Menggunakan Ampas Tebu Sebagai Adsorben, Jurnal Teknik Kimia, Jurusan Teknik Kimia, Fakultas Teknik Universitas Sriwijaya.

Ratna Dewi Kususmaningtyas, Nur Qudus, Rr. Dewi Artanti Putri, dan Rini Kusumawardani, 2018, Penerapan Teknologi Pengolahan Limbah Minyak Goreng Bekas Menjadi Sabun Cuci Piring Untuk Pengendalian Pencemaran dan Pemberdayaan Masyarakat, Jurusan Teknik Kimia, Fakultas Teknik, Universitas Negeri Semarang.

Rorong, Johnly, Henry Aritonang, dan Ferdian P Ranti, 2008, Sintesis Metil Ester Asam Lemak Dari Minyak Kelapa Hasil Pemanasan, Jurusan Tteknik Kimia Fakultas MIPA UNSRAT, Manado. 